\title{
Unsecured Credit, Moneylending \& Protection of a Social Minimum in Singapore
}

\author{
Jodi Gardner ${ }^{1,2, *}$ \\ ${ }^{1}$ Adjunct Research Fellow, Centre for Banking and Finance Law, National University of Singapore, Singapore \\ ${ }^{2}$ Lecturer in Law and Doctoral Researcher, Corpus Christi College, University of Oxford, UK \\ *Correspondence: E-mail: jodi.gardner@law.ox.ac.uk
}

Received: August 15, 2016

Accepted: September 5, 2016

Online Published: November 4, 2016

doi:10.5430/sass.v4n1p1

URL: http://dx.doi.org/10.5430/sass.v4n1p1

\begin{abstract}
On 6 April 2015, the Singaporean Monetary Standards Authority (MAS) announced additional restrictions on the amount of unsecured credit Singaporean borrowers will be entitled to obtain from banks and other financial institutions. These restrictions will be phased in gradually over four years to allow people time to adjust to the new measures. The MAS restrictions are occurring at the same time as the Ministry of Law's (MinLaw) implementation of a new aggregate borrowing cap on moneylending loans. The aim of these restrictions are to reduce the levels of over-indebtedness in Singapore, which is a very worthy goal. There is concern however from some stakeholders that these limitations could have a flow-on effect to other areas, namely pushing vulnerable borrowers into more expensive or harmful forms of credit. As the MAS restrictions come into force, people may be tempted to move from mainstream unsecured credit to moneylending which is generally more expensive, but is not covered by the MAS cap. In light of these issues, this paper analyses the current regime in relation to unsecured credit and moneylending. It considers the aims and potential unforeseen outcomes of the MAS and MinLaw restrictions, as well as the ability of the borrowing limitations to stop over-indebtedness and protect a socially minimal standard of living for borrowers in Singapore.
\end{abstract}

Keywords: moneylending; social minimum; unsecured credit; poverty; illegal lending

\section{Introduction}

The Monetary Authority of Singapore has for a number of years been analysing the regulation of unsecured credit. There have been multiple consultations undertaken and a variety of potential reforms implemented. In April 2015, the MAS announced restrictions on the amount of unsecured credit to which borrowers in Singapore are entitled. These will be phased in gradually over four years to allow people time to adjust, but by June 2019 there will be a strict limit of 12 times borrowers' monthly income. The restrictions aim to reduce over-indebtedness in Singapore, which is a very worthy goal. There are however some concerns with the flow-on effects of the limitations, including the fact that the levels do not include a wide variety of other forms of credit, and that the limitations may push vulnerable borrowers into more expensive or harmful forms of credit, including increased use of moneylenders and potentially illegal lending.

In light of these issues, this paper will analyse the aims and potential unforeseen outcomes of the current regime, and the role that the protection of social minimums could play in helping structure future reforms in this area. There are three Parts. The first outlines the regulation of unsecured credit in Singapore, including the MAS reforms, the limitations on borrowing, and the recent changes to the moneylending regulations. The second Part considers the impact of the regulatory reforms, including the potential for financial exclusion, the Repayment Assistance Scheme, and the impact of reduced borrowing. The final Part analyses the reforms and the impact they could have on borrowing in Singapore, including whether one of the aims should be the protection of a social minimum. The paper will finish by outlining a series of recommendations and areas for further research, including the impact that the MAS limitations could have on personal insolvency in Singapore. 


\section{Part A: The Regulation of Unsecured Credit in Singapore}

This Part will outline the significant amendments that have occurred in the regulation of unsecured credit in Singapore since 2012. This will include a discussion of the initial MAS review and recommendations, followed by a consideration of the proposed limitations on unsecured credit borrowing levels, and finally a review of the recent moneylending regime reforms.

\subsection{Initial Review and Recommendations}

The regulation of unsecured credit in Singapore has been subject to ongoing regulatory review over the last three years. In December 2012, the Monetary Standards Authority (MAS) released a Consultation Paper on the credit cards and unsecured credit. The rules on these issues are part of the Singapore Government's policy to avoid excessive debt, and to discourage people from obtaining credit that they are then unable to repay without suffering from financial hardship. This will also hopefully prevent people from spending 'beyond their means'.(Note 1) The Consultation Paper put forward five aims for the regulatory regime in this area:

(a) improve financial institutions' lending practices;

(b) empower individuals to make better borrowing decisions;

(c) help individuals who are at risk of credit problems to avoid getting into greater debt;

(d) increase flexibility for financially secure retirees; and

(e) align rules across unsecured credit products. (Note 2)

In order to fulfil these aims, MAS provided a range of potential reforms and asked for public feedback on the recommendations. This paper will analyse the aims, and the specific reforms suggested to fulfil the aforementioned aims. It will suggest that while each of the aims is notable and important, one issue was overlooked, the importance of protecting a social minimum. A focus on ensuring that there is a socially minimal standard of living in Singapore implicitly underlines a number of the recommendations, and once this important goal is explicitly recognised and discussed, it will provide a number of additional approaches and reforms.

To improve financial institutions' lending practices, further credit checks were suggested. This included reviewing outstanding debt and credit limits in credit bureau checks, and requiring financial institutions to conduct further checks if (a) information is obtained that may impact the ongoing credit worthiness of the borrower or (b) prior to credit limit increases. The recommendations to empower individuals to take control of their finances included requirements that the cost of rolling credit is disclosed, credit limits can only be increased on the request and consent of borrowers, and borrowers should indicate their preferred credit limits on all application forms. To help individuals who are at risk of credit problems avoid further indebtedness, MAS recommended instituting limitations on further borrowing or charging. Further recommendations were also made regarding continuing access to credit cards for retirees who could afford the repayments, and aligning the rules on credit checks to credit cards with limit over $\$ 500$.

MAS provided significant opportunity for further public feedback and consultation. A response to the feedback received was issued in both September(Note 3) and November 2013. (Note 4) The responses received were generally quite positive, and it is clear that the community in general supports aims to reduce over-indebtedness and address problem credit by creating additional regulation in this area. (Note 5) A number of responses requested definitions for a terms used by MAS (for example, 'unsecured credit facility', 'outstanding amounts' and 'Singapore borrower'). (Note 6) Other responses questioned how the proposals would impact alternative forms of unsecured borrowing, such as renovation loans(Note 7) and business or corporate credit cards. (Note 8) There were also queries about how these rules would apply to existing borrowers and accounts(Note 9). In addition, there was legitimate concern about the requirements on financial institutions when a borrowers' credit worthiness was called into question, as this was quite a vague specification; MAS subsequently provided significant guidance on this requirement. (Note 10)

After reviewing the responses received from the consultation process, MAS issued draft rules on unsecured credit and credit cards in September 2013. (Note 11) These rules will apply gradually, to give both borrowers and financial institutions the opportunity to cope with the regime changes, some of which are quite significant. Starting in December 2013, financial institutions were required to conduct credit bureau checks on individuals before granting a new credit card or unsecured credit facility, and before approving credit increases. This is a direct recommendation from the MAS consultation process. In addition, financial institutions will have to disclose to borrowers the cost of rolling over their credit card debts, including explaining how the debt will accumulate. The aim of this is to empower borrowers and assist them to make more informed decisions about their borrower capacity. Financial institutions are 
now also required to obtain borrowers' express consent for every credit limit increase. This will hopefully provide borrowers with more control over the finances and debt levels.

One of the most controversial changes was the prohibition on granting further unsecured credit to individuals whose unsecured debts are more than 60 days overdue. This prohibition stays in place until all outstanding debt is paid. This was implemented with a similar requirement that financial institutions cannot grant further unsecured credit to individuals whose interest-bearing outstanding unsecured debt (across all institutions) exceeds 12 months of their income for 90 days or more. In both of these situations, other financial institutions are prohibited from granting new credit to the borrower, including new credit cards, unsecured credit facilities or increases in existing credit facilities.

From December 2014, borrowers themselves, as well as financial institutions, will be able to obtain a copy of borrowers' Credit Bureau Report. This will include all outstanding credit, including both secured and unsecured balances. (Note 12) This will empower borrowers to be more aware of their credit history and reports, as well as providing financial institutions will access to this important information.

In general, these provisions will assist those who are struggling to repay their existing debt to take control of their financial situation before it becomes any worse. There are however risks that it could result in individuals becoming financially excluded, and thus deteriorate both their financial and living situations. Recommendations such as these should be implemented in conjunction with an adequate safety net to ensure that borrowers do not need to turn to other, more expensive and harmful, forms of credit. These issues will be discussed in more depth below.

\subsection{Limitations on Borrowing}

In September 2013, MAS announced reforms designed to prohibit financial institutions from granting additional unsecured credit to a borrower whose existing aggregate unsecured debt (i.e. across all institutions) was over 12 times their monthly income for more than three months consecutively. Whilst the aim of this is to ensure that borrowers do not become overly indebted, there were significant concerns from both the Association of Banks in Singapore and Credit Counselling Singapore (as well as feedback received from the public) that such a drastic reform could result in financial exclusion and general hardship for borrowers who had become dependent on the higher levels of debt. For example, if borrowers were unable to reduce their borrowing in time, they may be forced to moneylenders, borrowing from family or friends, or potentially even illegal lenders.

On 6 April 2015, MAS announced additional restrictions on the amount of unsecured credit Singaporean borrowers will be entitled to obtain from banks and other financial institutions. These restrictions will be phased in gradually over four years to allow people time to adjust to the new measures. The proposed timeframe is:

- As of 1 June 2015, people will be unable to borrow more than 24 times their monthly income;

- As of 1 June 2017, people will be unable to borrow more than 18 times their monthly income; and

- As of 1 June 2019, people will be unable to borrow more than 12 times their monthly income.

The first stage of the process has been implemented, so people in Singapore are currently limited to borrowing 24 times their monthly income.

\subsection{Moneylending Reform}

Moneylending in Singapore has also recently come under significant scrutiny. The Ministry of Law and IPTO have both looked at these issues in depth, and during 2015 significant law reform was enacted. In 2014, the Advisory Committee on Moneylending was formed to review the existing framework and make its recommendations on measures for:

1) Capping of interest rates for moneylending loans;

2) Restricting the charging of fees by moneylenders;

3) Capping the aggregate amount of moneylending loans taken out by each borrower; and

4) Other policy parameters which could strengthen the moneylending regulatory regime.

The Committee is chaired by Mr Manu Bhaskaran, Director of Centennial Group International and Vice President of the Economics Society of Singapore, and comprises of 15 people from a range of backgrounds, including academics, community and grassroots organisations, members of the Moneylenders Association of Singapore and economists. After undertaking significant research into the moneylending industry in Singapore, the Committee released its draft recommendations in November 2014.

In light of the draft recommendations, the Ministry of Law and Advisory Committee undertook further discussions 
and reviews, and the final recommendations were released on 29 May 2015 at the Institute of Policy Studies Moneylending Conference. There were 15 recommendations made:

1) Limitations be placed on the amount of interest that can be charged, namely:

a. An upfront administrative fee of not more than $10 \%$ of the loan principal

b. Interest of not more than $4 \%$ per month

c. Late interest of not more than $4 \%$ per month

d. A late fee of not more than $\$ 60$ per month, and

e. Total borrowing costs to be capped at $100 \%$ of the loan principal.

2) Borrowers earning less than $\$ 20,000$ a year would be subject to an aggregate unsecured borrowing cap of $\$ 3,000$. They should be subject to an aggregate unsecured borrowing cap of six times of their monthly salary, as for all other borrowers. This cap is independent of the MAS cap discussed above.

3) The moratorium on the grant of new moneylending licences should be lifted.

4) The Ministry of Law should engage the voluntary welfare organisations that counsel distressed borrowers in order to undertake further research on moneylending borrowers. This is aimed to ascertain if there are borrowers who should not be borrowing from licensed moneylenders.

5) The Moneylenders Association of Singapore should work closely with the voluntary welfare organisations that assist distressed debtors to explore the feasibility of introducing a formalised debt restructuring regime.

6) No recommendations were made in respect of the location of moneylenders, although the Registry of Moneylenders should monitor the situation and ensure it is not aggravated.

7) The issue of aggregating credit information on borrowers be given consideration by policy makers.

8) Borrowers who are excluded from local casino premises be identified to moneylenders.

9) All moneylenders be required to keep to a set of standardised loan contracts and practices.

10) All moneylenders be required to incorporate as companies with a minimum paid-up capital of $\$ 100,000$, and submit annual audited accounts.

11) The advertising restrictions be removed to allow moneylenders some limited advertisement in the newspapers, subject to stringent regulation in of their advertising activities.

12) A set of guidelines for acceptable debt collection practices be created.

13) Before granting a loan, moneylenders be required to explain to borrowers the effects of late repayment on their overall debt, with concrete examples set out in dollar terms and explained to the borrower.

14) Loans to businesses that have been registered for at least two years will not be subject to the proposed controls on borrowing costs, as well as the aggregate unsecured borrowing cap.

15) The Registry should improve the collection of data from moneylenders.

These recommendations are strongly in line with the recommendations in this Report, which will be outlined in Part IV below. The Ministry of Law accepted 12 of the 15 recommendations. It rejected number 11, the removal of advertising restrictions, on the basis that it could lead to increased borrowing. Two other recommendations, the lifting of moratoriums on the granting of new licences and the creation of debt collecting guidelines, will be reviewed at a later stage.

\section{Part B: Impact of Regulatory Reforms}

The second Part of this paper will analyse the impact of the regulatory reforms discussed in Part A above. This includes the financial exclusion of individuals who were heavily indebted prior to the MAS reforms, the implementation of a Repayment Assistance Scheme, and an analysis of the impact of pushing people into more expensive forms of credit.

\subsection{How Many People will be Financially Excluded?}

The MAS restrictions are designed to prevent people from becoming dangerously over-indebted, which is an important and desirable aim. It will however mean that many people who had significant levels of debt will become excluded from the mainstream financial system until they can retain control over their borrowing. 
Data compiled by financial institutions and the Credit Bureau Singapore shows that, as at February 2015, 32,000 borrowers were going to be impacted by the reforms on 1 June 2015 which limited unsecured borrowing to 24 times the monthly income. This figure represents two per cent, or one in every 50, of borrowers in Singapore. When the 2019 reforms are introduced (limiting borrowing to 12 times the monthly salary), this number jumps up to 84,000 five per cent, or one in every 20 borrowers. These people will now be excluded from accessing further unsecured credit, and will need to try and reduce the amount of debt they already have outstanding. (Note 13)

Data from the Credit Bureau provides a profile of these over-indebted borrowers, and some of this information is quite surprising. Most of the heavily in-debt borrowers have some form of tertiary education and incomes around or above the median income level. Problem debt is not only an issue for low-income borrowers; it can affect all people. Kuo How Nam, the President of Credit Counselling Singapore, saw a high-earning borrower with an unsecured debt of $\$ 1.8$ million. (Note 14) These over-indebted borrowers owe approximately $\$ 7.5$ million, less than 0.4 per cent of the total banking assets in Singapore. MAS has reported that the borrowing of these individuals does not pose a risk to the local financial industry, whose aggregate non-performing loan ratio remains at a low 1.1 per cent. (Note 15)

\subsection{Repayment Assistance Scheme}

It was recognised that the borrowing limitations will have a detrimental impact on a number of borrowers who currently have debt levels above the 2015, 2017 and 2019 levels. The borrowing limitations require people to reduce their debt significantly. In recognition of this requirement, the Association of Banks in Singapore(Note 16) and Credit Counselling Singapore are working together on the introduction of a debt repayment solution, named the 'repayment assistance scheme'. This program will assist those who are currently borrowing over the specified levels to reduce the amount of outstanding debt by repaying loans at a set $5 \%$ per annum over a period of eight years(Note 17). There are strict requirements for eligibility to the program. The borrower must:

(a) Be a Singaporean citizen or permanent resident;

(b) Earn less than $\$ 10,000$ per month;

(c) Have less than $\$ 2,000,000$ in net personal assets;

(d) Have unsecured debt exceeding 12 times their grown (?) income;

(e) Be currently making monthly repayments and have a good repayment history. (Note 18)

Borrowers who are eligible for this program will be contacted by their financial institution with information on their outstanding debt, the repayment assistance scheme and how it can help them, and application forms for anyone who may be interested. Once the borrower completes and submits the application form and includes all the relevant supporting documents, the CCS will process the application if all the conditions are met. The CCS will then send a 'Repayment Proposal' to the borrower to review, sign and return. If the borrower chooses to accept the Repayment Proposal, they will sign and return the document to CCS, which will then forward it to the borrowers' financial institutions for further review and approval. The financial institutions will review the application and send a letter of acceptance or rejection to the borrower directly. (Note 19)

Borrowers had a 31 December 2015 cut off to apply for this program. It is unclear what if any help will be provided to borrowers in need of assistance who miss this date. The Frequently Asked Questions created by ABS and CCS comments that if borrowers do not qualify for the scheme, they should contact CCS to see what other types of restructuring options may be available. (Note 20)

\subsection{Pushing People into More Expensive Credit?}

One of the key aims of these restrictions is to reduce the levels of over-indebtedness in Singapore, which is a very worthy goal. There is concern however from some stakeholders that these limitations could have a flow-on effect to other areas, namely pushing vulnerable borrowers into more expensive or harmful forms of credit such as moneylending and potentially illegal lending. As the MAS restrictions come into force, people may be tempted to move from mainstream unsecured credit to moneylending, which is generally more expensive but is not covered by the MAS cap. Because moneylending is regulated by the Insolvency and Public Trustee's Office (and thus not MAS), the restrictions from MAS do not apply to this form of loans. There are however separate limitations in place for moneylending, as discussed in Part I.

This section explores how much it will cost borrowers to move loans from unsecured loans with financial institutions and into moneylending. In 2014 the average monthly income for Singaporean citizens and permanent residents was $\$ 3,949$. (Note 21) This means that someone on the average wage can currently borrow $\$ 94,776$, creating an approximate monthly interest repayment of $\$ 710.82$ - approximately $18 \%$ of the borrowers total income. This does 
not however accurately reflect the financial situation, as people from all different financial backgrounds need to borrow money. To highlight the impact of being cut off from unsecured credit, three tables have been created to show the increasing costs of different types of credit. The first table looks at borrowers in the $11^{\text {th }}-20^{\text {th }}$ income percentiles, the second looks at borrowers in the $31^{\text {st }}-40^{\text {th }}$ percentile, and the final table focuses on the average monthly income.

Table 1. Interest Repayments for 11th-20th Percentile Earners

\begin{tabular}{|c|c|c|c|c|}
\hline & $\begin{array}{l}\text { Monthly } \\
\text { repayment(Note } \\
\text { 22) }\end{array}$ & $\begin{array}{l}2015 \text { Reforms } \\
(24 \times \text { income) } \\
\text { (Note 23) }\end{array}$ & $\begin{array}{l}2017 \text { Reforms } \\
\text { (18 x income) }\end{array}$ & $\begin{array}{l}2019 \\
\text { Reforms (12 } \\
x \text { income) }\end{array}$ \\
\hline $\begin{array}{l}11^{\text {th }}-20^{\text {th }} \text { percentile }(\$ 971) \text { unsecured loan at } \\
0.75 \% \text { EIR per month(Note } 24)\end{array}$ & $\$ 7.28$ & $\$ 174.78$ & $\$ 131.09$ & $\$ 87.39$ \\
\hline $\begin{array}{l}11^{\text {th }}-20^{\text {th }} \text { percentile }(\$ 971) \text { credit card at } \\
1.25 \% \text { EIR per month(Note } 25)\end{array}$ & $\$ 12.14$ & $\$ 291.30$ & $\$ 218.48$ & $\$ 145.65$ \\
\hline $\begin{array}{l}\left.11^{\text {th }}-20^{\text {th }} \text { percentile ( } \$ 971\right) \text { moneylending } \\
\text { loan at } 4 \% \text { EIR per month(Note } 26 \text { ) }\end{array}$ & $\$ 38.84$ & $\$ 932.16$ & $\$ 699.12$ & $\$ 466.08$ \\
\hline $\begin{array}{l}11^{\text {th }}-20^{\text {th }} \text { percentile }(\$ 971) \text { moneylending } \\
\text { loan in default at } 8 \% \text { EIR per month }+\$ 60 \\
\text { late fee(Note } 27)\end{array}$ & $\$ 137.68$ & $\$ 1,924.32$ & $\$ 1,458.24$ & $\$ 992.16$ \\
\hline
\end{tabular}

Table 2. Interest Repayments for 31st-40th Percentile Earners

\begin{tabular}{|c|c|c|c|c|}
\hline & & $\begin{array}{l}2015 \text { Reforms } \\
\text { (24 x income) }\end{array}$ & $\begin{array}{l}2017 \text { Reforms } \\
(18 \times \text { income })\end{array}$ & $\begin{array}{l}2019 \text { Reforms } \\
\text { (12 x income) }\end{array}$ \\
\hline $\begin{array}{l}31^{\text {st }}-40^{\text {th }} \text { percentile }(\$ 1,747) \text { unsecured loan } \\
\text { at } 0.75 \% \text { EIR per month }\end{array}$ & $\$ 13.10$ & $\$ 314.46$ & $\$ 235.85$ & $\$ 157.23$ \\
\hline $\begin{array}{l}31^{\text {st }}-40^{\text {th }} \text { percentile }(\$ 1,747) \text { credit card at } \\
1.25 \% \text { EIR per month }\end{array}$ & $\$ 21.84$ & $\$ 524.10$ & $\$ 392.08$ & $\$ 262.05$ \\
\hline $\begin{array}{l}31^{\text {st }}-40^{\text {th }} \text { percentile }(\$ 1,747) \text { moneylending } \\
\text { loan at } 4 \% \text { EIR per month }\end{array}$ & $\$ 69.88$ & $\$ 1,677.12$ & $\$ 1,257.84$ & $\$ 838.56$ \\
\hline $\begin{array}{l}31^{\text {st }}-40^{\text {th }} \text { percentile }(\$ 1,747) \text { moneylending } \\
\text { loan in default at } 8 \% \text { EIR per month }+\$ 60 \\
\text { late fee }\end{array}$ & $\$ 199.76$ & $\$ 3,414.24$ & $\$ 2,575,68$ & $\$ 1,737.12$ \\
\hline
\end{tabular}

Table 3. Interest Repayments for Average Income Earners

\begin{tabular}{|c|c|c|c|c|}
\hline & Monthly & $\begin{array}{l}2015 \text { Reforms } \\
\text { (24 x income) }\end{array}$ & $\begin{array}{l}2017 \text { Reforms } \\
(18 \mathrm{x} \text { income })\end{array}$ & $\begin{array}{l}2019 \text { Reforms } \\
\text { (12x income) }\end{array}$ \\
\hline $\begin{array}{l}\text { Average income }(\$ 3,949) \text { unsecured loan at } \\
0.75 \% \text { EIR per month }\end{array}$ & $\$ 29.62$ & $\$ 710.82$ & $\$ 533.11$ & $\$ 355.41$ \\
\hline $\begin{array}{l}\text { Average income }(\$ 3,949) \text { credit card at } \\
1.25 \% \text { EIR per month }\end{array}$ & $\$ 49.36$ & $\$ 1,184.70$ & $\$ 888.53$ & $\$ 592.35$ \\
\hline $\begin{array}{l}\text { Average income }(\$ 3,949) \text { moneylending loan } \\
\text { at } 4 \% \text { EIR per month }\end{array}$ & $\$ 157.96$ & $\$ 3,791.04$ & $\$ 2,843.28$ & $\$ 1,895.52$ \\
\hline $\begin{array}{l}\text { Average income }(\$ 3,949) \text { moneylending loan } \\
\text { in default at } 8 \% \text { EIR per month }+\$ 60 \text { late fee }\end{array}$ & $\$ 375.92$ & $\$ 7,642.08$ & $\$ 5,746.56$ & $\$ 3,851.04$ \\
\hline
\end{tabular}

Please note, the moneylending figures are solely there to show how different, more sub-prime forms of credit can be significantly more expensive than 'standard' unsecured credit loans. Thus reforms to reduce access to unsecured credit may have the detrimental consequence of pushing people into more expensive credit. As discussed above, 
there are new restrictions on moneylending laws so that people can only borrow an amount of six months of their annual salary, and people earning less than $\$ 20,000 /$ annum can borrow a maximum of $\$ 3,000$.

\section{Part C: Analysis of Reforms}

This Part continues on from the earlier section, and analyses the potential impact of the reforms discussed in Part A. This includes a discussion on the fact that the limits on lending are still not aggregate debt and so people can continue to become over-indebted and unable to repay their loans without going into financial hardship, the role that protection of social minimums can play in the regulation of moneylending, and finally how the current limits are treating the symptoms - and not the cause - of over-indebtedness.

\subsection{Protection of a Social Minimum?}

The current reforms raise the question of whether MAS is limiting debt levels in an attempt to protect a socially minimal level of living. The protection of a 'social minimum' is a philosophical concept aimed at ensuring that all people living in society have access to an agreed minimum standard of life. Protection of a social minimum is highly relevant to the regulation of credit; when people become over-indebted, the interest repayments may push them below the social minimum level.

The concept is widely debated, particularly around how the specific level is agreed. There is an ongoing debate on whether the level of a social minimum is an absolute or relative concept. As outlined by Amartya Sen, the 'social minimum' level can vary substantially

from such elementary things as being adequately nourished, being in good health, avoiding escapable morbidity and premature mortality, etc., to more complex achievements such as being happy, having self-respect, taking part in the life of the community. (Note 28)

The exact level of a social minimum will depend on the community in which the individual is based, and the level of resources held by that community. Richer communities will generally have a higher standard of living, thus a higher social minimum.

Different academics and philosophers have framed social minimums in a variety of ways, although they also focus on identifying what it means to be a human and live a life of dignity. For example, Martha Nussbaum framed the concept of a social minimum by using capabilities - that is by identifying central human functional capabilities that people need to live a life that is truly 'human'. (Note 29) By determining what capabilities the Singaporean government believe are essential to live an adequate life, regulatory regimes can be based around protecting and ensuring these capabilities.

Whilst protecting a social minimum may seem foreign to a country such as Singapore, which does not generally consider itself a 'welfare state', this important concept is already embedded into the Singaporean system in a number of ways. Two examples of how a social minimum is already playing a role in the legal system in Singapore are minimum (sometimes called 'basic') wage levels and bankruptcy laws. The former aims to ensure that all people are paid adequate remuneration for their work.(Note 30) The latter allows people who become over-indebted a second chance with a specified level of income and assets to keep them going - provided they are repaying their loans to the extent possible without falling below the social minimum.

Mr Wong Nai Seng, Assistant Managing Director (Policy, Risk \& Surveillance) said

All of us have to take active steps to manage our unsecured debts so that they do not become unsustainable. Most borrowers do not spend or borrow beyond their means, but some may need help to reduce their debts gradually. If you need help, we encourage you to act early and approach your FIs or CCS for assistance. (Note 31)

There is an initial indication that the reforms already in place demonstrate a concern to protect a social minimum preventing people from spending or borrowing beyond their means and thus potentially dipping below a social minimum. The paper argues that the protection of a social minimum is an important driver behind the current approach to unsecured credit and credit card levels. Whilst it has not been explicitly identified as one of the government's aims of reform, there is a strong indication of concern for social minimum outlined by the desire to prevent over-indebtedness and thus limit how much unsecured debt people can borrow at one time. Once protection of a social minimum is recognised as a legitimate and important goal for regulation of credit, it can assist with the development of law reform. For example, in Australia there are strong responsible lending guidelines that prohibit lenders from granting credit to people unless the loans are suitable and the borrowers will be able to repay the loans 
without it causing them significant hardship. If a loan is granted in breach of the responsible lending guidelines, it is non-enforceable and the lenders can be penalised by the Australian regulator. (Note 32) In addition, when people are on low-incomes, (Note 33) a maximum of $20 \%$ of their income can go to servicing outstanding debt. This helps to protect $80 \%$ of their income and ensure they have access to a minimum level of resources. (Note 34)

\subsection{Need to Limit Aggregate Debt}

The current regulations are an important and useful step forward, in that they limit access to unsecured credit across all financial institutions as opposed to individual institutions. There are however significant restrictions on the types of debt that are covered by the MAS limitations, which means that people can obtain access to other forms of credit and may continue to become over-indebted. As discussed above, moneylending is not covered by the MAS restrictions and therefore borrowers will be able to obtain both unsecured credit and moneylending loans. An example of those this could lead to over-indebtedness can be shown in the potential borrowing capabilities of someone in the $11^{\text {th }}-20^{\text {th }}$ percentile of earnings (equating to $\$ 971 /$ month):

- Total level of unsecured borrowing currently allowed: $\$ 23,304=24$ x $\$ 971$ (unsecured loan) $+\$ 3,000$ (moneylending)

- $\quad$ Cost of borrowing: $\$ 294.78-\$ 411.30=\$ 120$ (moneylending at $4 \%$ on $\$ 3,000)+\$ 174.78-\$ 291.30$ (unsecured loan or credit card)

- Cost of borrowing in default: $\$ 474.78-\$ 591.30$ = as above, with default interest and a late fee

Even with the current limitations, the borrower could still be required to repay over half their monthly income in interest payments from unsecured borrowing. This would put the borrower significantly below any sort of socially minimal standard of living.

This situation is further exacerbated by the fact that a number of other loans, including loans for education, business and medical purposes, are exempt from the limitation. Loans for business or commercial purposes are also not covered by the restrictions. The limitation only relates to unsecured credit as well, so further debt can be incurred as long as there is security for the credit advanced.

Whilst there are important reasons behind the exclusion of these types of credit from the MAS restriction, it must be recognised that the exclusion can - and probably will - have a detrimental impact on the financial security of many borrowers. The strict lending limits may not be enough to adequately protect borrowers; prior to advancing further credit, financial institutions should also be confident that the borrower in question will be able to repay the loan without suffering undue hardship. This is one of the key aspects of the responsible lending regime in Australia. The responsible lending rules in Australia form part of the National Consumer Credit Protection Act 2009 (NCCPA), which applies to all forms of consumer credit, secured or unsecured. The core obligation of lenders is to ensure that the credit contract is 'not unsuitable' for the borrower. The lender has an obligation to verify information provided by the consumer about their financial position to ensure that the credit is not unsuitable. The Explanatory Memorandum for the NCCPA states that at a minimum, the lender is required to 'understand the purpose for which the credit is sought and determine if the type, length, rate, terms, special conditions, charges and other aspects of the proposed contract meet this purpose'. This type of approach could be a useful consideration for future reform, particularly due to the increased access to credit bureau information on potential borrowers.

\subsection{Treating the Symptom, Not the Cause}

Limiting access to credit will have a helpful impact on levels of over-indebtedness and problem debt in Singapore. It is however only treating the symptoms of a larger issue - why are increasing numbers of people getting access to such large amounts of unsecured credit? If the borrower cannot repay their existing loans, they will need to take out further credit and can become stuck in a harmful debt cycle. To understand this issue and treat the cause of the problem, we need to be able to identify why people are becoming so indebted. There has been some data collected on this issue. Credit Counselling Singapore President Kuo How Nam noted that amongst the main reasons for over-indebtedness were overspending on lifestyle wants; job-related - i.e. the borrower or a family member loses their job; failed investments; lending money to family or friends which are not repaid; and gambling (25\% of people with significant debts stated this as a key factor in their financial position). (Note 35) Further data can easily be obtained by keeping records of borrowers using the Repayment Assistance Scheme.

The government should recognise this issue and provide adequate support for vulnerable borrowers in Singapore. This support has two main parts - firstly, helping people manage their finances to prevent getting into problem debt, and secondly providing services for people who do become overly indebted to help them regain control of their 
finances. These support organisations and services are not designed to give indebted borrowers an 'easy way out', but instead provide them with support and assistance so that they can take control of their financial situation. (Note 36) Similar programs are currently run in a number of other countries, including the Money Advice Service and StepChange Debt Charity in the United Kingdom, and the Financial Counsellors Association in Australia. These organisations provide assistance to people who are suffering financial difficulties so that they can repay their existing debts without obtaining further credit.

One effective way to reduce consumers' reliance on different forms of high-cost credit is to increase the affordable and appropriate credit options available to them. This would give consumers better choices to respond to the financial ups and downs of life without having to resort to expensive and potentially harmful credit options. This is an important way forward; there are however many significant challenges that will need to be addressed. One illuminating model of banks reaching out and assisting those in need is the No-Interest Loan / Low-Interest Loan Scheme (NILS/LILS) being run by the National Australia Bank and Good Shepherd Microfinance, which has assisted over 100,000 financially excluded Australian borrowers to access affordable credit in times of need. Further information about this program is provided in Appendix 1.

\section{Conclusion and Recommendations}

The MAS should be congratulated on the hard work they have put into regulation of unsecured credit thus far. It is clear that there has been a significant amount of thought, research and consultation into these complicated issues. This paper provides a number of recommendations to further develop the good work that has already been done in this area. These recommendations include:

- A consideration of the role that protection of a social minimum can play in the regulation of credit in Singapore. This could include, for example, the implementation of responsible lending obligations and limitations on how much income low-income borrowers can use to repay existing debt.

- Combining the lending restrictions for unsecured credit and moneylending, so there is a single limitation on indebtedness levels. MAS and IPTO should also work together to ensure that the current limitations on unsecured credit does not result in a spike in the need for moneylending services in Singapore.

- Recognising that preventing people from accessing loans does not address the underlying need for credit; some people may be in such dire financial situations that they cannot afford to access commercial credit in any form. Whilst the Repayment Assistance Scheme is an excellent step forward, it has strict restrictions on who can access the service. It will therefore be important to ensure that there is a support network in place for people who, for a variety of reasons, cannot use the RAS.

- Collecting data on people using the Repayment Assistance Scheme, including why and how they have become so heavily indebted.

- Monitoring people who can no longer access unsecured credit to see whether they are turning to moneylending and/or going into personal insolvency instead. This should not be difficult due to the increased use of credit bureau information and requirements for financial institutions to run credit checks on borrowers.

This paper has also considered the relationship between the MAS unsecured credit restrictions and the levels of moneylending in Singapore. There is a further relationship that should also be analysed; the current restrictions have the potential to push increasing numbers of people into personal insolvency as they will no longer be able service their credit obligations. It would therefore be highly useful for further research to analyse the impact that the unsecured credit regime may have on insolvency levels and processes in Singapore.

In conclusion, the MAS restrictions on unsecured credit are likely to have a positive impact for a number of people who have become dangerously over-indebted. There are however some legitimate concerns that this approach could result in financial exclusion and/or push people to more expensive forms of credit, both of which are likely to exacerbate their financial difficulties. To minimise these externalities, the concept of protecting a social minimum provides a useful basis for further reform - particularly for people who are struggling with significant debt and low-income levels.

\section{Acknowledgement}

I would like to thank the Centre for Banking and Finance Law for their support of this research and paper. Thank you 
also to Sandra Booysen and Kenneth Khoo for their very valuable feedback on an earlier draft.

\section{References}

Adrian Lim. (2015). Easier for 2 VWOs to help debtors in repayments. Straits Times. Retrieved 27 November 2015 from http://www.straitstimes.com/singapore/easier-for-2-vwos-to-help-debtors-in-repayments

Amartya Sen. (1992). Inequality Reexamined. Oxford: Clarendon Press.

Elaine McCrate. (2003). Minimum wage or 'living' wage? The World \& I, 18, 56-61.

Imelda Saad. (2014). Debt Restructuring Programme for Debtors of Licensed Moneylenders. Channel News Asia. $\begin{array}{lllll}\text { Retrieved } & 22 & \text { November } & 2014 & \text { from }\end{array}$ http://www.channelnewsasia.com/news/singapore/debt-restructuring/1488140.html

Jodi Gardner. (2014). The Challenges of Regulating High-Cost Short-Term Credit: A Comparison of UK and Australian Approaches, CHASM Research Paper. Retrieved from http://www.birmingham.ac.uk/Documents/college-social-sciences/social-policy/CHASM/2014/the-challenges-o f-regulating-high-cost-short-term-credit-UK-and-Australia.pdf

Jodi Gardner. (2014). Regulating Moneylending in Singapore: Looking at All Sides, Centre for Banking \& Finance Law Research Policy Paper, National University of Singapore

Martha Nussbaum. (1999). Women and Cultural Universals' in Nussbaum. Sex and Social Justice. Oxford: Oxford University Press, pp. 29-54

Ministry of Manpower, 'Summary Table: Income', Retrieved from http://stats.mom.gov.sg/Pages/Income-Summary-Table.aspx

Monetary Authority of Singapore. MAS Will Phase In Borrowing Limit on Unsecured Credit. Retrieved from http://www.mas.gov.sg/news-and-publications/media-releases/2015/mas-will-phase-in-borrowing-limit-on-unse cured-credit.aspx

Monetary Authority of Singapore, Proposed Changes to Credit Cards and Unsecured Credit, Consultation Paper P008, September 2013

Monetary Authority of Singapore, Proposed Changes to Credit Cards and Unsecured Credit, Consultation Paper P024, December 2012

Monetary Authority of Singapore, Response to Feedback Received - Proposed Changes to Credit Card \& Unsecured Credit Rules, September 2013

Monetary Authority of Singapore, Response to Feedback Received - Public Consultation on Legislative Amendments to Credit Card and Unsecured Credit Rules, November 2013

Rachael Boon. (2015). MAS to phase in new limit on unsecured credit over four years, starting in June. The Straits $\begin{array}{lllll}\text { Times. } & \text { Retrieved } & 6 & \text { April } & 2015\end{array}$ http://www.straitstimes.com/business/banking/mas-to-phase-in-new-limit-on-unsecured-credit-over-four-yearsstarting-in-june

Rachael Boon. (2015). Well-educated, well-paid, but mired in debt. The Straits Time. Retrieved 8 April 2015 from http://www.straitstimes.com/business/well-educated-well-paid-but-mired-in-debt

The Association of Banks in Singapore and Credit Counselling Singapore, 'FAQ for RAS', Repayment Assistance Scheme Website, http://www.ccsras.org.sg/

The Association of Banks in Singapore and Credit Counselling Singapore, 'How Does RAS Work?', Repayment Assistance Scheme Website, http://www.ccsras.org.sg/

The Association of Banks in Singapore and Credit Counselling Singapore, 'Which are the Financial Institutions Participating in the RAS?', Repayment Assistance Scheme Website, http://www.ccsras.org.sg/

The Association of Banks in Singapore and Credit Counselling Singapore, 'Who is Eligible for RAS?', Repayment Assistance Scheme Website, http://www.ccsras.org.sg/ 


\section{Notes}

Note 1. Monetary Authority of Singapore, Proposed Changes to Credit Cards and Unsecured Credit, Consultation Paper P024, December 2012, p. i.

Note 2. Ibid.

Note 3. Monetary Authority of Singapore, Response to Feedback Received - Proposed Changes to Credit Card \& Unsecured Credit Rules, September 2013.

Note 4. Monetary Authority of Singapore, Response to Feedback Received - Public Consultation on Legislative Amendments to Credit Card and Unsecured Credit Rules, November 2013.

Note 5. Ibid.

Note 6. Ibid, pp. 2-4.

Note 7. Ibid, p. 4.

Note 8. Ibid, p. 11.

Note 9. Ibid, p. 14.

Note 10. Ibid, pp. 29-31.

Note 11. Monetary Authority of Singapore, Proposed Changes to Credit Cards and Unsecured Credit, Consultation Paper P008, September 2013.

Note 12. The Association of Banks in Singapore and Credit Counselling Singapore, 'FAQ for RAS', Repayment Assistance Scheme Website, http://www.ccsras.org.sg/, p. 10.

Note 13. Rachael Boon, 'MAS to phase in new limit on unsecured credit over four years, starting in June', The Straits Times, $\quad 6 \quad$ April $\quad$ 2015, available http://www.straitstimes.com/business/banking/mas-to-phase-in-new-limit-on-unsecured-credit-over-four-years-starti ng-in-june.

Note 14. Rachael Boon, 'Well-educated, well-paid, but mired in debt', The Straits Times, 8 April 2015, available at http://www.straitstimes.com/business/well-educated-well-paid-but-mired-in-debt.

Note 15. Rachael Boon, 'MAS to phase in new limit on unsecured credit over four years, starting in June', The Straits Times, $\quad 6 \quad$ April 2015, available http://www.straitstimes.com/business/banking/mas-to-phase-in-new-limit-on-unsecured-credit-over-four-years-starti ng-in-june.

Note 16. The banks involved in this scheme are American Express International Inc, Australia \& New Zealand Banking Group Ltd, Bank of China Ltd, CIMB Bank Berhad, Citibank Singapore Ltd, DBS Bank Ltd, Diners Club (Singapore) Pte Ltd, The Hongkong and Shanghai Banking Corporation Ltd, Industrial and Commercial Bank of China Ltd, Standard Chartered Bank (Singapore) Ltd, Malayan Banking Berhad, Oversea-Chinese Banking Corporation Ltd, RHB Bank Berhad, United Overseas Bank Ltd; see The Association of Banks in Singapore and Credit Counselling Singapore, 'Which are the Financial Institutions Participating in the RAS?', Repayment Assistance Scheme Website, http://www.ccsras.org.sg/.

Note 17. The banks involved in this scheme are American Express International Inc, Australia \& New Zealand Banking Group Ltd, Bank of China Ltd, CIMB Bank Berhad, Citibank Singapore Ltd, DBS Bank Ltd, Diners Club (Singapore) Pte Ltd, The Hongkong and Shanghai Banking Corporation Ltd, Industrial and Commercial Bank of China Ltd, Standard Chartered Bank (Singapore) Ltd, Malayan Banking Berhad, Oversea-Chinese Banking Corporation Ltd, RHB Bank Berhad, United Overseas Bank Ltd; see The Association of Banks in Singapore and Credit Counselling Singapore, 'Which are the Financial Institutions Participating in the RAS?', Repayment Assistance Scheme Website, http://www.ccsras.org.sg/.A borrower who is on RAS will have his debt divided into two portions: (a) Amounts up to 12 times his monthly income - Amounts up to 12 times his monthly income are to be repaid in accordance with the respective terms and conditions of the borrower's existing facilities. Financial institutions will inform their customers of the monthly payment that needs to be made; (b) Amounts in excess of 12 times his monthly income - Amounts in excess of 12 times his monthly income will be managed under RAS and are to be repaid in accordance with the terms and conditions of RAS (i.e. 5\% per annum over 8 years); The Association of Banks in Singapore and Credit Counselling Singapore, 'How Does RAS Work?', Repayment Assistance Scheme Website, http://www.ccsras.org.sg/. 
Note 18. The Association of Banks in Singapore and Credit Counselling Singapore, 'Who is Eligible for RAS?', Repayment Assistance Scheme Website, http://www.ccsras.org.sg/. This includes a requirement that the borrower has not had any accounts involuntarily close or debt written off and there are no bankruptcy petitions in the CBS report: see The Association of Banks in Singapore and Credit Counselling Singapore, 'FAQ for RAS', Repayment Assistance Scheme Website, http://www.ccsras.org.sg/, p. 6.

Note 19. The Association of Banks in Singapore and Credit Counselling Singapore, 'FAQ for RAS', Repayment Assistance Scheme Website, http://www.ccsras.org.sg/, p. 6.

Note 20. The Association of Banks in Singapore and Credit Counselling Singapore, 'FAQ for RAS', Repayment Assistance Scheme Website, http://www.ccsras.org.sg/, p. 9.

Note 21. Ministry of Manpower, 'Summary Table: Income', available at http://stats.mom.gov.sg/Pages/Income-Summary-Table.aspx. Please note, this amount excludes full-time national servicemen.

Note 22. Figures are calculated on a flat-rate basis without any fees and charges (unless specifically stated).

Note 23. For further discussion about the moneylending reforms, see Jodi Gardner, Regulating Moneylending in Singapore: Looking at All Sides, Centre for Banking \& Finance Law Research Policy Paper, National University of Singapore.

Note 24. Interest calculated from the Citibank unsecured loan of $9 \%$ annual interest rate, see https://www.citibank.com.sg/gcb/landing_page/clickforcash/clickcash/apply-personal-loan.htm.

Note 25. Interest calculated from the average 2014 credit card annual interest rate of 15.07\% - see Kelly Dilworth, 'Average credit card interest rate raises to 15.07\%', Creditcards.com, http://www.creditcards.com/credit-card-news/interest-rate-report-100114-up-2121.php.

Note 26. Interest based on the moneylending cap implemented on 1 October 2015.

Note 27. These figures are illustrative only, as there are separate loan caps for moneylenders (currently six months for borrowers earning above $\$ 20,000$ /annum and $\$ 3,000$ for those earning below $\$ 20,000$ ).

Note 28. Amartya Sen (1992) Inequality Reexamined, Oxford: Clarendon Press, p. 39.

Note 29. These are (1) the capability for physical survival; (2) the capability for bodily health; (3) the capability for bodily integrity; (4) the capability for the exercise of imagination; (5) the capability for emotional response and exploration; (6) the capability for practical reason; (7) the capability for love and friendship; (8) the capability for connection with nature and other species; (9) the capability for play; and (10) the capability for the exercise of control over environment, including political control; Martha Nussbaum (1999) 'Women and Cultural Universals' in Nussbaum, Sex and Social Justice, Oxford: Oxford University Press, pp. 29-54. Whilst the majority are reasonable uncontentious, the last few capabilities are clearly up for debate, particularly their application to developing countries.

Note 30. This is however a controversial issue. Minimum wages are generally not considering 'living wages', the latter of which is associated with social minimums; Elaine McCrate (2003) 'Minimum wage or 'living' wage?' The World \& I, Vol 18, pp. 56-61.

Note 31. Monetary Authority of Singapore, 'MAS Will Phase In Borrowing Limit on Unsecured Credit', available at http://www.mas.gov.sg/news-and-publications/media-releases/2015/mas-will-phase-in-borrowing-limit-on-unsecure d-credit.aspx.

Note 32. For further discussion on the Australian responsible lending regime, see Jodi Gardner (2014) The Challenges of Regulating High-Cost Short-Term Credit: A Comparison of UK and Australian Approaches, CHASM Research Paper, available at http://www.birmingham.ac.uk/Documents/college-social-sciences/social-policy/CHASM/2014/the-challenges-of-reg ulating-high-cost-short-term-credit-UK-and-Australia.pdf.

Note 33. Defined in Australia has having 50\% or more of their income from government sources.

Note 34. See discussion in Jodi Gardner (2014) The Challenges of Regulating High-Cost Short-Term Credit: A Comparison of UK and Australian Approaches, CHASM Research Paper, available at http://www.birmingham.ac.uk/Documents/college-social-sciences/social-policy/CHASM/2014/the-challenges-of-reg ulating-high-cost-short-term-credit-UK-and-Australia.pdf, p. 10. 
Note 35. Rachael Boon, 'Well-educated, well-paid, but mired in debt', The Straits Times, 8 April 2015, available at http://www.straitstimes.com/business/well-educated-well-paid-but-mired-in-debt.

Note 36. Although there are hopes that this will change shortly - Imelda Saad, 'Debt Restructuring Programme for Debtors of Licensed Moneylenders', Channel NewsAsia 22 November 2014, http://www.channelnewsasia.com/news/singapore/debt-restructuring/1488140.html. Steps have been taken to move this initiative forward. In November 2015, a memorandum of understanding was signed by two VWOs, together with the Moneylender's Association of Singapore and DP Information Network, which manages DP SME Commercial Credit Bureau; Adrian Lim, 'Easier for 2 VWOs to help debtors in repayments', Straits Times, 27 November 2015, available at http://www.straitstimes.com/singapore/easier-for-2-vwos-to-help-debtors-in-repayments. Unfortunately, Credit Counselling Singapore was not one of the two VWOs involved in this program. 